\title{
Nf2/Merlin controls progenitor homeostasis and tumorigenesis in the liver
}

\author{
Samira Benhamouche, ${ }^{1,3}$ Marcello Curto, ${ }^{1,3}$ Ichiko Saotome, ${ }^{1}$ Andrew B. Gladden, ${ }^{1}$ Ching-Hui Liu, ${ }^{1}$ \\ Marco Giovannini, ${ }^{2}$ and Andrea I. McClatchey ${ }^{1,4}$ \\ ${ }^{1}$ Department of Pathology, Massachusetts General Hospital Center for Cancer Research, Harvard Medical School, Charlestown, \\ Massachusetts 02129, USA; ${ }^{2}$ Center for Neural Tumor Research, House Ear Institute, Los Angeles California 90057, USA
}

The molecular signals that control the maintenance and activation of liver stem/progenitor cells are poorly understood, and the role of liver progenitor cells in hepatic tumorigenesis is unclear. We report here that liverspecific deletion of the neurofibromatosis type 2 ( $N f 2)$ tumor suppressor gene in the developing or adult mouse specifically yields a dramatic, progressive expansion of progenitor cells throughout the liver without affecting differentiated hepatocytes. All surviving mice eventually developed both cholangiocellular and hepatocellular carcinoma, suggesting that $\mathrm{Nf}^{-/-}$progenitors can be a cell of origin for these tumors. Despite the suggested link between $N f 2$ and the Hpo/Wts/Yki signaling pathway in Drosophila, and recent studies linking the corresponding Mst/Lats/Yap pathway to mammalian liver tumorigenesis, our molecular studies suggest that Merlin is not a major regulator of YAP in liver progenitors, and that the overproliferation of $\mathrm{Nf2}^{-/-}$liver progenitors is instead driven by aberrant epidermal growth factor receptor (EGFR) activity. Indeed, pharmacologic inhibition of EGFR blocks the proliferation of $\mathrm{Nf}^{-/-}$liver progenitors in vitro and in vivo, consistent with recent studies indicating that the Nf2-encoded protein Merlin can control the abundance and signaling of membrane receptors such as EGFR. Together, our findings uncover a critical role for Nf2/Merlin in controlling homeostasis of the liver stem cell niche.

[Keywords: EGFR; Merlin; NF2; cholangiocellular carcinoma; hepatocellular carcinoma; liver progenitor]

Supplemental material is available at http://www.genesdev.org.

Received April 17, 2010; revised version accepted June 18, 2010.

The remarkable regenerative capacity of the mammalian liver is well known (Fausto et al. 2006; Michalopoulos 2007). In response to liver cell loss, existing hepatocytes and cholangiocytes (bile duct cells) re-enter the cell cycle to maintain or restore the original liver volume and biliary tree. When pathological or experimental conditions that block hepatocyte proliferation also exist, facultative liver progenitor cells, known in rodents as "oval cells" (OCs) for their morphological appearance (Farber 1956), emerge and expand from the most terminal branches of the biliary tree (Fausto and Campbell 2003; Fausto 2004; Roskams et al. 2004; Alison 2005; Theise 2006). Like embryonic hepatoblasts (HBs), OCs are considered to be bipotential, and can give rise to both hepatocytes and cholangiocytes (Evarts et al. 1987; Sell 2001). Cells that are thought to be equivalent to OCs have been identified in humans, and are presumed to also be liver progenitors (Roskams et al. 2004). However, it has not been possible to define the origin, potential, or molecular features of human liver progenitor cells.

\footnotetext{
${ }^{3}$ These authors contributed equally to this work.

${ }^{4}$ Corresponding author.

E-MAIL mcclatch@helix.mgh.harvard.edu; FAX (617) 726-7808.

Article published online ahead of print. Article and publication date are online at http://www.genesdev.org/cgi/doi/10.1101/gad.1938710.
}

Chemically induced liver tumors in mice often feature an initial expansion of OCs, suggesting that they can be the cell of origin of at least some liver tumors (Sell 2001; Roskams 2006). However, genetically defined animal models that feature primary OC expansion are rare (Jakubowski et al. 2005). Instead, OCs appear in some genetically engineered models of liver tumorigenesis, but only secondary to hepatocellular dysplasia/neoplasia and inflammation (Sandgren et al. 1989; Santoni-Rugiu et al. 1996; Lu et al. 2010; Song et al. 2010), precluding an investigation of the molecular signals that govern OC proliferation, identification of the OC niche, and delineation of the link between OCs and liver tumorigenesis.

The paucity of genetically defined mouse models has also impeded progress in defining the cellular and molecular bases of liver cancer, the third leading cause of cancer death in humans (Llovet et al. 2003). The two most common types of liver cancer are hepatocellular carcinoma (HCC) and cholangiocarcinoma (CC; bile duct cancer); mixed tumors with features of both HCC and CC also occur (Llovet et al. 2003; Blechacz and Gores 2008). Rodent models of liver tumorigenesis have traditionally relied on chemical induction, which yields HCC almost exclusively and CC only rarely (Lee et al. 1997; Sell 2001). Some transgenic models of HCC have been 
developed, but these involve overexpression of specific oncogenes throughout the liver (Sandgren et al. 1989; Murakami et al. 1993; Dong et al. 2007); genetically engineered mouse models of CC are rare (Kiguchi et al. 2001; Xu et al. 2006). Few examples of liver tumorigenesis in tumor suppressor mutant strains of mice have been reported (Colnot et al. 2004; Xu et al. 2006; Zhou et al. 2009; Lu et al. 2010; Song et al. 2010). However, mice carrying a heterozygous mutation in the neurofibromatosis type 2 (NF2) tumor suppressor gene spontaneously develop both HCC and CC (McClatchey et al. 1998; Kalamarides et al. 2002). Liver tumor initiation and progression was not studied in these animals because of the predominant development of osteosarcomas and other tumors.

The NF2-encoded protein Merlin is closely related to the membrane:cytoskeleton-linking proteins Ezrin, Radixin, and Moesin (the ERM proteins), and can associate with a number of membrane-associated proteins and receptors (McClatchey and Fehon 2009). Recent studies reveal that Merlin can control the abundance of certain membrane receptors in mammalian cells and in flies, including the epidermal growth factor receptor (EGFR) (Maitra et al. 2006; Curto et al. 2007; Cole et al. 2008; Lallemand et al. 2009). In mammalian cells, Merlin can block EGFR internalization and signaling specifically in response to cell:cell contact, providing one explanation for the loss of contactdependent inhibition of proliferation exhibited by Nf2deficient cells (Morrison et al. 2001; Lallemand et al. 2003; McClatchey and Giovannini 2005; Okada et al. 2005; Curto et al. 2007; Morris and McClatchey 2009). Indeed, pharmacologic inhibitors of EGFR block the overproliferation of $\mathrm{Nf2}^{-/-}$cells in culture and within $\mathrm{Nf2}^{-/-}$ renal tumors in vivo (Curto et al. 2007). Increasing evidence indicates that physical communication between stem cells and the surrounding niche regulates their proliferation and ability to divide asymmetrically, which could render them particularly sensitive to Nf2 loss (Fuchs et al. 2004; Yamashita et al. 2005; Scadden 2006).

We wanted to study the role of Nf2/Merlin in controlling proliferation in the developing and adult mouse liver in order to better understand the predisposition of $N f 2$ heterozygous mutant mice to liver tumorigenesis and the potential role of Nf2-regulated pathways in human liver malignancies. We found that deletion of Nf2 in the developing liver leads to a rapid and dramatic expansion of liver progenitor cells throughout the liver, and subsequently to the development of CC and metastatic HCC. Loss of Nf2 in the adult liver yields equivalent histopathological lesions, suggesting that Nf2 is required to both establish and maintain the hepatic progenitor cell niche; all of these mice also go on to develop both CC and HCC. Notably, $\mathrm{Nf}^{-/-}$hepatocytes in these models remained quiescent, and were even able to participate in normal liver regeneration, indicating that progenitor cells are uniquely sensitive to Nf2 loss. Despite recently established links between the Drosophila Nf2 ortholog and the Hpo/Wts/Yki proliferation control pathway in flies (Hamaratoglu et al. 2006; Hamaratoglu et al. 2009; Baumgartner et al. 2010; Genevet et al. 2010; Yu et al. 2010), and between the corresponding mammalian Mst/
Lats/Yap pathway in hepatocyte quiescence and tumorigenesis (Zender et al. 2006; Dong et al. 2007; Zhou et al. 2009; Lu et al. 2010; Song et al. 2010), our studies suggest that Merlin is not a major regulator of Mst/Lats/Yap in mouse liver progenitors. Instead, our studies suggest that, as in other cell types, a key function of Merlin in these cells is to negatively regulate the activity of EGFR. Thus, pharmacologic inhibition of EGFR blocks the overproliferation of liver progenitors in this model, consistent with studies that conclude that EGFR signaling promotes OC proliferation (Evarts et al. 1993; Nagy et al. 1996) and liver tumorigenesis in humans and rodents (Jhappan et al. 1990; Breuhahn et al. 2006; Tanabe et al. 2008). These studies yield novel insights into the cellular and molecular basis of liver progenitor homeostasis, the biological function of the Nf2 tumor suppressor, and the relationship between liver progenitors and tumorigenesis.

\section{Results}

Nf2 deletion causes liver progenitor expansion and hepatomegaly

To isolate the consequences of Nf2 deficiency to the liver, we crossed conditional $N f 2$ mutant $\left(N f 2^{\text {lox/lox }}\right)$ mice to transgenic Alb-Cre mice in which the albumin promoter drives expression of the Cre recombinase in the developing and adult liver (Postic and Magnuson 2000). Liver-specific deletion of Nf2 led to marked abdominal enlargement beginning at 6-8 wk of age due to massive hepatomegaly, with livers representing up to one-third of the total body weight (Fig. 1A,B; Supplemental Fig. 1A,C). Surprisingly, histological examination revealed that this was not due to an increase in hepatocyte number or size, but instead to extensive hyperplasia of undifferentiated cells that fit the morphological description of facultative mouse liver progenitor cells known as OCs (Fig. 1C,D). These lesions originated from the portal tracts and infiltrated the surrounding parenchyma, leaving the centrilobular veins largely intact (Fig. 1D). Indeed, while cells within these lesions were highly proliferative, islands of neighboring $\mathrm{Nf2^{-/- }}$ hepatocytes remained quiescent and exhibited no apparent defects (Fig. 1D,F). Apoptotic cells were not detected in the lesions or in neighboring hepatocytes (data not shown).

The albumin promoter becomes active in HBs at embryonic day 9.5 (E9.5) in the developing mouse liver, and its activity is maintained postnatally in mature hepatocytes but not in mature cholangiocytes (Shiojiri 1981). Bona fide OCs have not been described in the embryo, but their correspondence with HBs within the primitive biliary tree has been suggested (Shiojiri et al. 1991). In fact, periductular hyperplasia is already detectable in newborn $\mathrm{Alb}-\mathrm{Cre} ; \mathrm{Nf2} 2^{\text {lox/lox }}$ livers, which are otherwise normal (Fig. 2B). Thus, the earliest histopathological consequences of Nf2 deficiency are restricted to the prospective locations of the adult liver stem cell niches from which OCs arise (Theise et al. 1999; Kuwahara et al. 2008; Sell and Leffert 2008), suggesting that Merlin plays an important role in the initial establishment of the liver progenitor niche. 

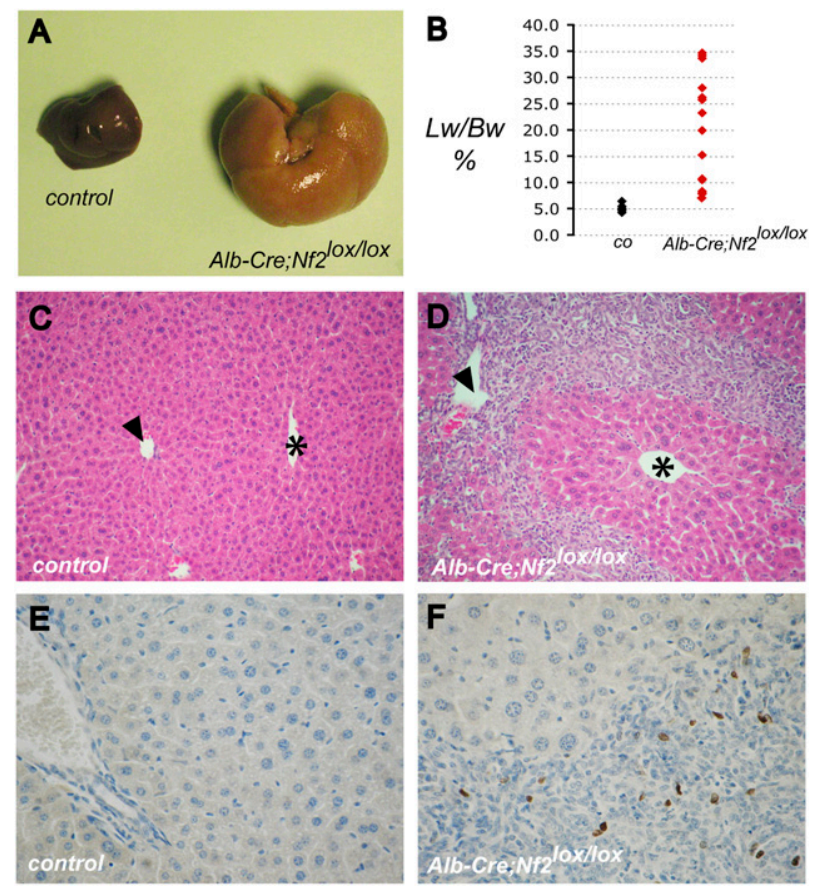

Figure 1. Targeted deletion of Nf2 in the mouse liver results in massive hepatic enlargement due to OC hyperproliferation. $(A)$ Hepatomegaly exhibited by the liver of a 20 -wk-old Alb-Cre; $N f 2^{\text {lox/lox }}$ mouse (right) relative to the liver from a control $N f 2^{\text {lox } / \text { lox }}$ littermate (left). (B) Distribution of liver weight:body weight ratios in $A l b-C r e ; N f 2^{l o x} /$ lox $(r e d)$ versus control (black) mice between 1 and 4 mo of age. Livers of $A l b-C r e ; N f 2^{10 x / l o x}$ mice comprise up to one-third of the body mass. $(C, D)$ Hematoxylinand eosin-stained paraffin sections of 9-wk-old littermates reveals marked periportal expansion of OCs throughout AlbCre; $N f 2^{\text {lox/lox }}(D)$ but not control $(C)$ livers. Portal veins (arrowheads) and centrilobular veins (asterisks) are denoted $(200 \times)$. $(E, F)$ As revealed by BrdU incorporation, proliferation in $A l b$ $C r e_{i} N f 2^{\text {lox/lox }}$ livers is limited to the OCs, and is not seen in surrounding hepatocytes (shown in $F$ ). (E) BrdU-incorporating cells are essentially undetectable in the control liver. A single BrdU pulse was given $2 \mathrm{~h}$ before sacrifice $(400 \times)$.

The expansion of OC-containing lesions in postnatal $A l b$-Cre; $N f 2^{10 x / l o x}$ livers is progressive, yielding cords that radiate from and bridge the portal tracts to strikingly delineate the polygonal architecture of hepatic lobuli (Fig. 2C). As proliferation of OCs and associated cholangiocyte-like cells proceeds, immature neoductuli are formed (Fig. 2B). Despite some regional variation, the phenotypic penetrance is complete, ultimately leading to a diffuse and massive OC expansion that surrounds and progressively compromises islands of normal-appearing hepatocytes (Fig. 2C,D). Thus, Nf2 loss is sufficient for the sustained overproliferation of liver progenitors in vivo.

Consistent with classic models of OC hyperplasia in the mouse, cells throughout the $A l b-C r e ; N f 2^{l o x / l o x}$ liver lesions were marked by anti-pan-cytokeratin (panCK), A6, and anti-CD34 antibodies (Fig. 3B,C,E,F,H,I,K,L,N; Omori et al. 1997; Crosby et al. 2001; Jakubowski et al. 2005; Kofman et al. 2005; Lee et al. 2006). In contrast, in the wild-type liver, expression of the panCK and A6 antigens are restricted to bile duct epithelial cells (BECs) (Fig. 3D,J,M); likewise, CD34 is normally expressed only by BECs and endothelial cells (Fig. 3G,J). Cells within the lesions did not express $\alpha$-smooth muscle actin, as would be seen upon activation of hepatic stellate cells during fibrosis, and we did not detect infiltrating lymphocytes or other signs of inflammation (data not shown). Taken together, these observations suggest that deletion of $N f 2$ yields an early, primary, and specific expansion of liver progenitor cells without affecting differentiated hepatocytes.

Deregulated EGFR signaling drives the overproliferation of $\mathrm{Nf}^{-1-}$ liver progenitors in vitro and in vivo

Recent studies suggest that Merlin and the related tumor suppressor Expanded can function together to regulate the $\mathrm{Hpo} / \mathrm{Wts} / Y k i$ tumor suppressor pathway in Drosophila, but it is not clear whether they are key regulators of the analogous mammalian Mst/Lats/Yap pathway (Edgar 2006; Hamaratoglu et al. 2006, 2009; Baumgartner et al. 2010; Genevet et al. 2010; Yu et al. 2010). If Merlin regulates Mst/Lats/Yap in mammalian liver cells, the presence or absence of Nf2 should confer changes in the phosphorylation and/or localization of the transcriptional activator Yap1 (Zhao et al. 2008). However, the localization and phosphorylation of Yap1 is not altered by endogenous or exogenous Merlin and/or Expanded in cultured OCs derived from early Alb-Cre;Nf2 ${ }^{l o x / l o x}$ lesions (for their derivation and characterization, see the Materials and Methods; Supplemental Fig. 2) or HBs, even at very high cell density (Supplemental Figs. 3A-E, 4B,C; J Gervais and AI McClatchey, unpubl.). In contrast, exogenous Lats did yield a clear increase in cytoplasmic Yap1 in both HBs and OCs (Supplemental Fig. 3E,F; data not
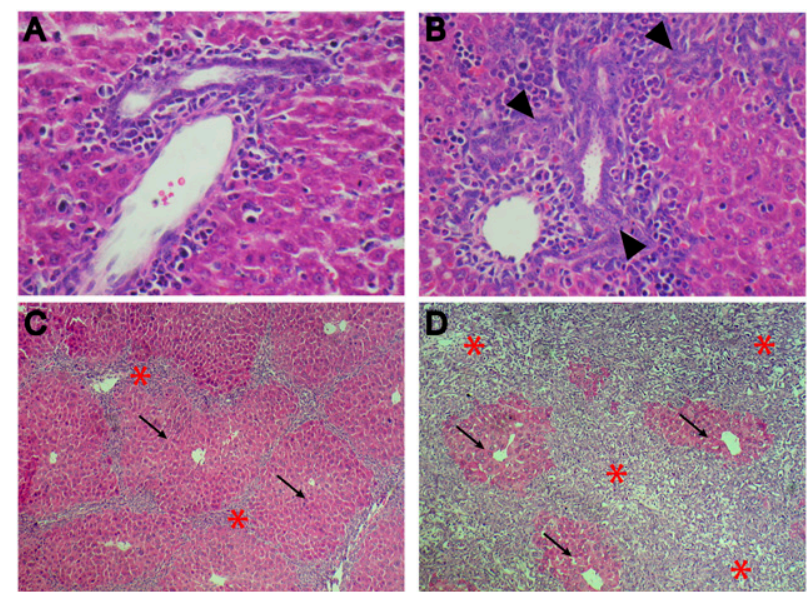

Figure 2. Evolution of OC hyperplasia in Alb-Cre; $N f 2^{l o x} /$ lox mice. Hematoxylin- and eosin-stained sections reveal that thickening of portal spaces (arrowheads) is already detectable in neonatal (postnatal day 3 [P3]) Alb-Cre;Nf2 ${ }^{\text {lox/lox }}$ livers $(B)$ compared with $N f 2^{\text {lox/lox }}$ control littermate livers $(A)(600 \times) .(C, D)$ Massive and progressive expansion of OCs (asterisks) in the liver of 3-wk-old $(C)$ and 15-wk-old $(D)$ Alb-Cre; $N f 2^{\text {lox/lox }}$ mice entraps residual foci of perivenous hepatocytes (arrows) (200×). 

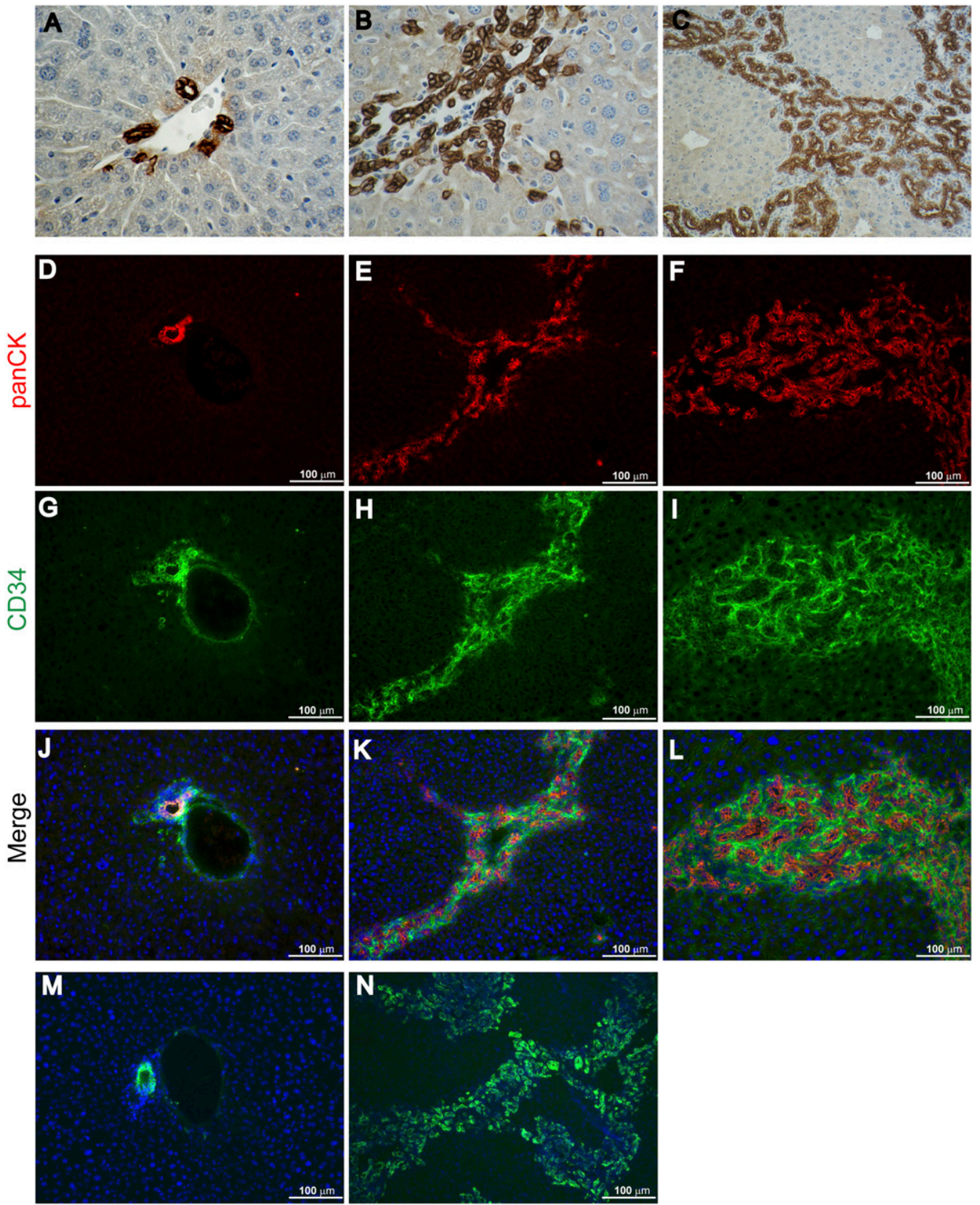

Figure 3. Expression of classic OC markers in $N f 2^{-1-}$ liver lesions. $(A-C)$ Immunohistochemical analysis using an anti-panCK antibody reveals prominent and progressive staining of the expanding OC population in the liver of 3-wk-old $(B)(600 \times)$ and 9-wk-old $(C)$

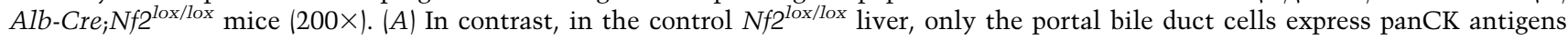
$(600 \times)$. $(D-L)$ Immunofluorescent detection of panCK and CD34 reveals prominent expression throughout the expanding lesions in 3-wk-old $(E, H, K)$ and 9-wk-old $(F, I, L)$ Alb-Cre; $N f 2^{\text {lox/lox }}$ livers, compared with the control $N f 2^{\text {lox/lox }}$ liver $(D, G, J)$. $(G, J)$ CD34 staining of portal vein endothelium is also apparent in the control. Costaining of the lesions with anti-CD34 and anti-panCK antibodies is shown in $K$ and $L .(M, N)$ The well-known A6 antibody, which shares epitopes with the panCK antibody (Kofman et al. 2005; Jelnes et al. 2007), similarly exhibits prominent staining throughout the lesions $(N)$, but detects only BECs in the normal liver $(M)$.

shown). Similarly, the expression of Yap1 target genes was not altered by the presence or absence of Merlin in confluent OCs or HBs (Supplemental Fig. 4A,B). Most importantly, shRNA-mediated knockdown of Yap1 did not rescue the loss of contact-dependent inhibition of proliferation exhibited by cultured $\mathrm{Nf2}^{-/-}$OCs (Supple- mental Fig. 4C,D). Thus, Merlin does not appear to be a major regulator of Yap1 in liver progenitors, and Yap1 does not mediate the overproliferation of $\mathrm{Nf2}^{-/-}$liver progenitors.

We found previously that Merlin can associate with and negatively regulate EGFR internalization and signaling 
specifically in contacting cells (Curto et al. 2007; Cole et al. 2008). Indeed, $N f 2^{-l-}$ cells of several types, including OCs and HBs, fail to down-regulate EGFR signaling at high cell density or to undergo contact-dependent inhibition of proliferation-phenotypes that are reversed by pharmacologic inhibition of EGFR (Curto et al. 2007). To determine whether persistent EGFR signaling drives the overproliferation of $\mathrm{Nf}^{-1-}$ liver progenitors in vivo, we treated a small cohort of 7-wk-old Alb-Cre; $N f 2^{\text {lox } / l o x}$ mice with erlotinib (100 mg/ $/ \mathrm{kg}$ in $6 \%$ captisol twice daily; $n=4$ ) or vehicle $(6 \%$ captisol twice daily; $n=3)$. After only $10 \mathrm{~d}$ of erlotinib treatment, we observed a decrease in lesion size and in liver:body weight ratio in all erlotinib-treated mice (Fig. 4A,B,F,G). This was accompanied by a marked reduction in the number of BrdU-positive cells within the lesions (Fig. 4C-E), and a corresponding decrease in the levels of pTyr and of known EGFR targets in these same cells (Fig. 4H; Supplemental Fig. 5). Notably, erlotinib treatment had no effect on Yap1 levels or localization in these cells (data not shown). Collectively, these data suggest that persistent EGFR signaling drives the overproliferation of $\mathrm{Nf2}^{-/-}$liver progenitor cells in vitro and in vivo.

\section{Liver tumorigenesis in Alb-Cre; $N f 2^{\text {lox/lox }}$ mice}

Between 6 and 30 wk of age, OC hyperplasia leads to the

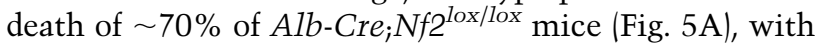
a progressive loss of hepatocyte-derived mass (see Fig. $2 \mathrm{C}, \mathrm{D}$ ) and frequent ascites secondary to portal hypertension. Both genders were affected equally. All mice that survived beyond $30 \mathrm{wk}$ exhibited increasing dysplasia and eventually developed frank liver tumors (Fig. 5B-G; Supplemental Fig. 6). Surviving Alb-Cre; ff2 $^{\text {lox/lox }}$ mice invariably developed both HCC and CC within the same liver (Fig. 5B-D). The HCCs exhibit a striking variety of histopathological types including trabecular, solid, pseudoductular, and acinar hepatocellular morphologies (Supplemental Fig. 6). Early CCs strongly resemble the "cholangiolocellular" subtype described in humans (Komuta et al. 2008) that exhibits poorly differentiated characteristics and is believed to originate from the Canal of Hering - a putative location of the adult liver stem cell niche (Fig. 5D; Supplemental Fig. 6). Transitional cellular and histological features intermediate between HCC and CC were also frequently observed (Supplemental Fig. 6). As seen in $\mathrm{Nf2}^{+/-}$mice, HCC metastases were found in the lungs of nearly all (13 out of 14) of these mice after $1 \mathrm{yr}$ (Fig. 5E-G; McClatchey et al. 1998). Other than lung metastases, no other extrahepatic lesions were detected. By crossing Alb-Cre; $N f 2^{\text {lox/lox }}$ mice with GtRosa26 $6^{\text {lox/stop/lox }}$ reporter mice, we confirmed that virtually all cells in primary CCs, HCCs, and corresponding metastases are lacZ-positive, and therefore originated from cells that expressed the Cre recombinase at some point and became Nf2-deficient (Fig. 5F,G; data not shown). This was confirmed by immunoblotting of dissected liver and tumor tissues (Supplemental Fig. 1C). The complete penetrance of both tumor types subsequent to OC expansion is consistent with the possibility that the tumors in these mice can derive from unregulated $\mathrm{N} f 2^{-1-}$ OCs.
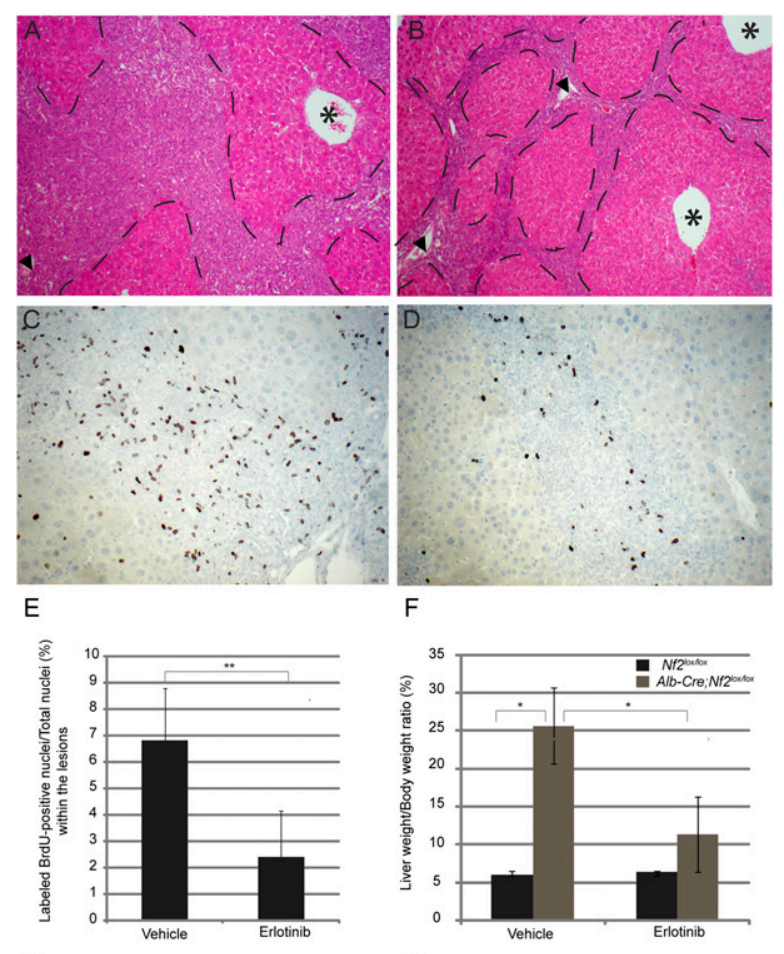

G

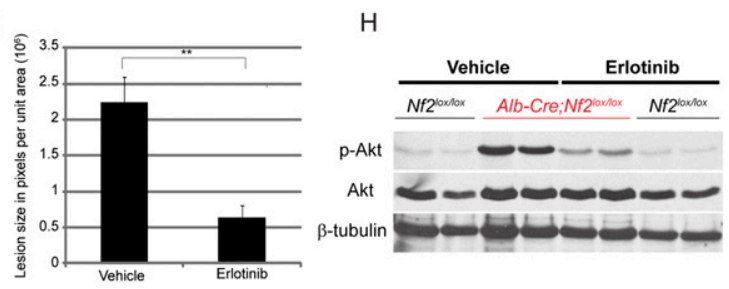

Figure 4. Deregulated EGFR signaling drives the overproliferation of $N f 2^{-/-}$liver progenitors in vivo. $(A, B)$ After only $10 \mathrm{~d}$ of erlotinib treatment, a reduction of the lesion area (outlined by dashed lies) is apparent in Alb-Cre;Nf2 ${ }^{\text {lox/lox }}$ mice $(B)$ compared


captisol $(A)$. Hematoxylin and eosin-stained sections are shown $(100 \times)$. Portal veins (arrowheads) and centrilobular veins (asterisks) are denoted. $(C, D)$ Immunohistochemical detection of BrdU incorporation reveals a marked decrease in proliferating OCs within the lesions in erlotinib-treated Alb-Cre; $\mathrm{Nf2}{ }^{\text {lox/lox }}$ mice $(D)$ compared with the vehicle-treated littermates $(C)(200 \times)$. A single BrdU pulse was given $2 \mathrm{~h}$ before sacrifice. $(E)$ Quantification of the erlotinib-induced decrease in BrdU-incorporating OCs in vivo. For each liver sample, $\sim 3000$ to $\sim 5000$ OC nuclei were counted. The graph reflects the number of BrdU-positive nuclei per total nuclei within the lesions across multiple animals $(n=4$ for erlotinib group; $n=3$ for vehicle group). $\left(^{\star \star}\right) P<0.05$. $(F)$ Distribution of liver weight:body weight ratios in Nf2 $2^{l o x} /$ lox (gray) versus $A l b-C r e ; N f 2^{\text {lox/lox }}$ (black) mice treated with vehicle and erlotinib. After only $10 \mathrm{~d}$, erlotinib treatment led to a reduction in the proportion of the total body mass accounted for by the liver (liver weight:body weight ratio), from $25 \%$ in vehicle-treated $A l b$ Cre; $N f 2^{\text {lox } / l o x}$ mice to $10 \%$ in erlotinib-treated Alb-Cre;Nf2 $2^{\text {lox } / l o x}$ mice. $\left({ }^{\star}\right) P<0.1$. $(G)$ Quantification of lesion size in vehicle- and erlotinib-treated mice. Liver lesion size is represented by pixels (occupied by lesion) per total unit area $\left.\left(270 \mathrm{~nm}^{2}\right) .{ }^{\star \star}\right) P<0.05$. $(H)$ In vivo administration of erlotinib yields a decrease in the levels of pAKT in Alb-Cre; $N f 2^{l o x / l o x}$ livers. Nf2 $2^{\text {lox/lox }}$ mice were used as controls. Western blots of total liver extracts representative of three independent experiments are shown. 

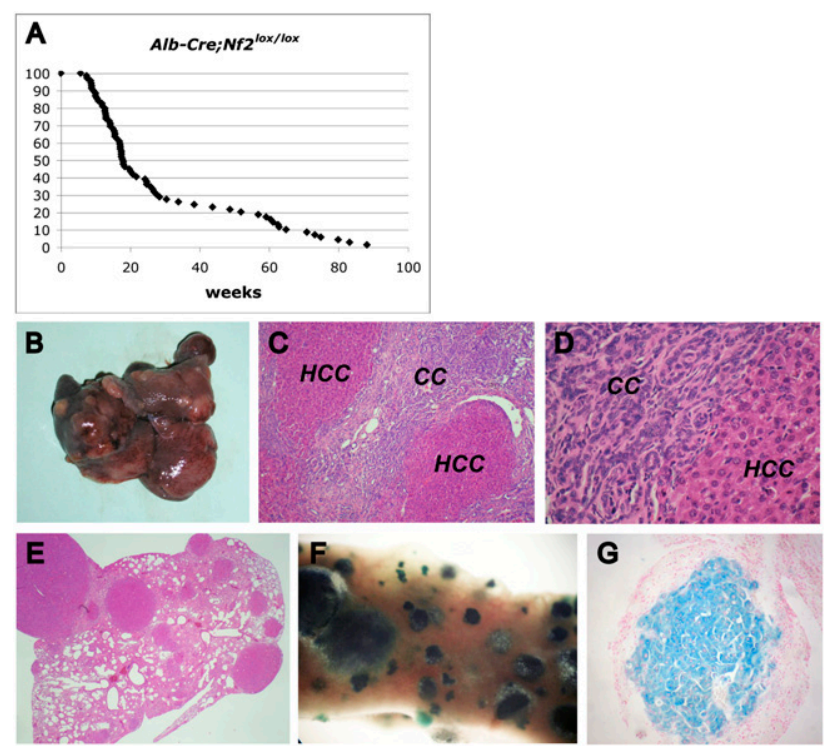

Figure 5. Metastatic liver tumor development in Alb-Cre; $N f 2^{l o x / l o x}$ mice. (A) Survival of Alb-Cre; $N f 2^{l o x / l o x}$ mice. While many animals died within a few months of age, likely due to compromised liver function, those that survived beyond $\sim 30$ wk all developed frank HCC and CC. (B) Multiple tumors are macroscopically evident in a 64-wk-old Alb-Cre; $\mathrm{Nf} 2^{10 x / l o x}$ liver. $(C, D)$ Hematoyxlin and eosin staining reveals both $C C$ and HCC neoplasias in the liver of an 83-wk-old Alb-Cre;Nf2 ${ }^{10 x / l o x}$; GtRosa26 ${ }^{10 x / s t o p / l o x}$ mouse. (C) 100×. (D) 400×. (E-G) Lung metastases from the liver shown in $C$. Hematoxylin and eosin staining $(40 \times)$. HCC metastases in the lung exhibit LacZ expression, as revealed by whole-mount $(F)$ and paraffin section $(G)$.

OC proliferation and tumorigenesis upon Nf2 deletion in adult mice: role of proliferative stimuli

To determine whether loss of Nf2 must occur in the context of the developing liver in order for OC expansion and tumorigenesis to ensue, we deleted Nf2 in the adult liver by injecting a Cre-expressing adenovirus (Ad-Cre) into 8-wk-old $\mathrm{Nf} 2^{\text {lox } / \text { lox }}$ mice (Fig. 6A). After 8-12 mo, only mild periportal hyperplasia was detected in the livers of these mice (Fig. 6B,D); hepatocyte alterations were not detectable, and neither CC nor HCC developed. We reasoned that the highly proliferative context of the developing liver in Alb-Cre; Nf2 ${ }^{l o x / l o x}$ embryos might play a critical role in the response to Nf2 loss, as the normal adult liver is mitotically quiescent. Therefore, we induced proliferation in the liver of $\mathrm{Ad}$-Cre-injected mice via partial hepatectomy $(\mathrm{PHx})$ (Higgins and Anderson 1931). As seen in Alb-Cre; $N f 2^{l o x / l o x}$ mice, all of these mice developed marked primary OC hyperplasia and subsequent HCC and CC (Fig. 6C,E; data not shown). OC hyperplasia was never seen upon PHx of control mice. As an alternative strategy, we generated $\mathrm{Mx} 1-\mathrm{Cre} ; \mathrm{Nf2} 2^{\mathrm{lox} / \mathrm{lox}}$ mice in which Cre expression can be induced throughout the liver upon stimulation of the interferon pathway via intraperitoneal injection of polyIC (polyinosinic-polycytidylic acid) (Fig. 6F; Kuhn et al. 1995). Again, Cremediated inactivation of $\mathrm{Nf2}$ in adult Mx1-Cre; $\mathrm{Nf2} 2^{l o x / l o x}$ mice resulted in only a modest activation of OCs after 5-8 mo, despite clear evidence of Nf2 recombination/loss throughout the liver (Fig. 6G; Supplemental Fig. 1B). However, performing a PHx after polyIC induction led

\section{A}

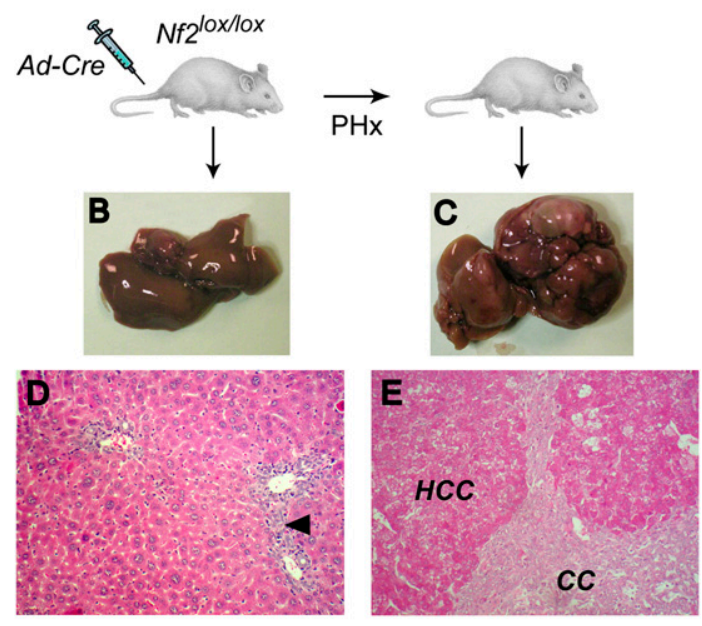

$\mathbf{F}$
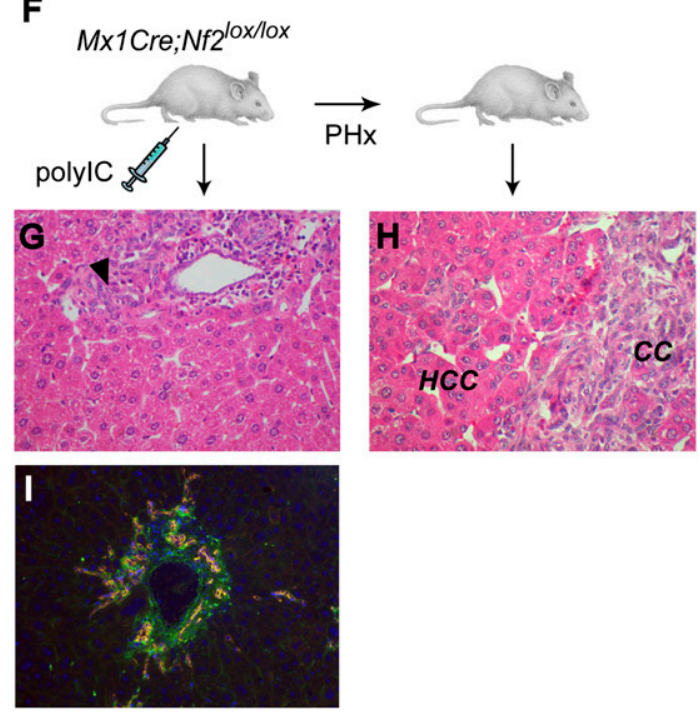

Figure 6. Deletion of $N f 2$ in the adult liver yields OC hyperproliferation and tumor development that are promoted by $\mathrm{PHx}$. (A) Two-month-old $N f 2^{\text {lox/lox }}$ mice were injected with Ad-Cre, followed 2 wk later by two-third PHx or sham operation, and were sacrificed 8 mo to 1 yr post-PHx. The liver from nonhepatectomized mice $(B)$ reveals only mild periportal OC hyperplasia (arrowhead) (D). In contrast, Ad-Cre-injected mice develop multiple liver tumors $(C)$ of both CC and HCC types $(E)$ when subjected to proliferative stimuli induced by $\mathrm{PHx} .(D, E)$ Hematoxylin and eosin-stained sections $(200 \times)$. (F) Two-month-old Mx1-Cre; $\mathrm{Nf} 2^{\text {lox/lox }}$ mice were intraperitoneally injected with polyIC, subjected to PHx or sham operation after $2 \mathrm{wk}$, and sacrificed at 7-8 mo. $(G, H)$ Hematoxylin and eosin-stained sections reveal mild periportal OC hyperplasia (arrowhead) in control, nonhepatectomized mice $(G)$, and both CC and HCC in mice subjected to $\mathrm{PHx}(H)(400 \times) .(I)$ As in Alb-Cre; $N f 2^{\text {lox/lox }}$ livers, lesions in hepatectomized, polyIC-induced $\mathrm{Mx} 1$-Cre $; \mathrm{Nf2} 2^{\text {lox } / l o x}$ livers express the OC markers panCK (red) and CD34 (green) $(400 \times)$. 
to a marked increase in OC hyperplasia, as well as HCC and CC development with complete penetrance (Fig. $6 \mathrm{H}, \mathrm{I})$. Notably, after PHx, liver regeneration itself occurs normally in the absence of Merlin, and $\mathrm{Nf}^{-/-}$hepatocytes re-enter a quiescent state after regeneration is complete; this is followed by the appearance and expansion of OCs. Thus, the proliferative stimulus provided by $\mathrm{PHx}$ appears to specifically unleash the overproliferation of otherwise quiescent $N f 2^{-/-}$liver progenitors, and is not required for their continued proliferation. This is consistent with a role for Merlin in down-regulating growth factor receptor output in liver cells. In fact, intraperitoneal injection of EGF into $\mathrm{Mx} 1-\mathrm{Cre} ; \mathrm{Nf2}^{\mathrm{lox} / \mathrm{lox}}$ mice yielded a "superinduction" of phosphorylated EGFR and the known EGFR signaling targets pSTAT3 and pAKT in the $\mathrm{Nf2}^{-/-}$ (polyIC-induced) relative to the control liver (no polyICmediated induction of Cre expression) (Supplemental Fig. 7). Taken together, these findings suggest that Merlin function is required to establish and maintain quiescence of liver progenitor cells.

\section{Stem/progenitor cell-derived tumorigenesis}

The overproliferation of OCs preceding the development of both HCC and CC in all three models suggests that the tumors originate from these liver progenitor cells. To determine whether undifferentiated $N f 2^{-/-}$liver progenitors can become neoplastic, we generated clonal lines of Nf2-expressing (wild-type) or Nf2-deficient HBs that also expressed a lacZ reporter from E14.5 embryonic mouse livers, and transplanted them into the livers of adult immunocompromised $\mathrm{nu} / \mathrm{nu}$ mice (Supplemental Fig. 1D). Five weeks post-transplantation, lac + +Nf2-expressing HBs were scattered uniformly throughout the liver (Fig. $7 \mathrm{~A}, \mathrm{~B})$. In contrast, livers from mice transplanted with Nf2-deficient HBs revealed multiple foci of proliferating undifferentiated cells that progressed within only 3-4 wk to form larger neoplasias that exhibited both cholangiocytic and hepatocytic features (Fig. 7C-F). These data support a cell-autonomous requirement for Merlin in controlling liver progenitor proliferation and neoplastic transformation; they also indicate that liver neoplasia can arise from clonal $\mathrm{Nf}^{-/-}$liver progenitors.

\section{Discussion}

The results presented here provide the first example of a single gene ( $N f 2$ ) whose disruption is sufficient to effect a primary expansion of both embryonic and adult liver progenitor cells in vivo, and to reproducibly yield both major forms of liver cancer. The lesions that arise upon deletion of $N f 2$ in embryonic or adult mouse liver strongly resemble classic models of chemically induced OC expansion both histologically and in terms of marker expression (Omori et al. 1997; Jakubowski et al. 2005; Kofman et al. 2005; Lee et al. 2006). Our phenotype also closely resembles the OC expansion seen upon transgenic overexpression of the TNF-like cytokine TWEAK (Jakubowski et al. 2005). However, in contrast to the $N f 2^{-/-}$liver, lesions in TWEAK-overexpressing livers exhibit increased apoptosis and are not progressive. Indeed, tumors do not develop in these mice. The precise origin of OCs has been long debated; most studies conclude that they arise from unidentified intrahepatic stem cells (Fausto and Campbell 2003; Fausto 2004; Theise 2006), although a hematopoietic origin has been suggested (Petersen et al. 1999; Thorgeirsson and Grisham 2006). Recently, label retention studies have partially substantiated the long-held notion that OCs arise from intraductal and periductal locations within the most proximal branches of the biliary tree (Kuwahara et al. 2008); this is precisely where OC expansion is first seen in Nf2-deficient livers. In fact, the initial appearance of OCs in newborn animals, despite more pervasive expression of $A l b$-Cre, suggests that Nf2 is specifically required for OC quiescence during the establishment of the OC niche. Together with the development of additional sophisticated genetic tools, this model could be used to define the cellular origin of the OC and the physical location of its niche.

Our data suggest that Nf2 mutant liver tumors are derived from $N f 2^{-1-}$ progenitors for the following reasons: First, OC expansion always precedes the development of both HCC and CC, regardless of whether Nf2 loss occurs in the embryo or adult. Second, lesions in all three models $\left(A l b-C r e ; N f 2^{l o x / l o x}, A d-C r e\right.$-injected $N f 2^{l o x / l o x}$, and polyICinduced $\left.M x 1-C r e ; N f 2^{l o x / l o x}\right)$ always contain transitional cellular morphologies with both hepatocytic and biliary features. Third, transplantation of clonal $\mathrm{Nf2} 2^{-/-} \mathrm{HBs}$ yielded the expansion of undifferentiated cells followed by the development of neoplasias bearing cholangiocytic and hepatocytic features, indicating that $\mathrm{Nf2}^{-\mathrm{l}}$ liver progenitors can initiate liver tumors. We cannot exclude the possibility that HCCs can develop from differentiated hepatocytes in the Nf2-deficient liver, given that hepatocytes continue to express Alb-Cre. However, Nf2 deficiency is clearly not sufficient for the overproliferation or transformation of differentiated hepatocytes, as AlbCre; $N f 2^{l o x / l o x}, A d$-Cre-injected $N f 2^{l o x / l o x}$, and induced $M \times 1-C r e ; N f 2^{l o x / l o x}$ mice harbor many Nf2-deficient hepatocytes that do not exhibit gross morphological alterations or aberrant BrdU incorporation in vivo; in fact, liver regeneration occurs normally in these mice, indicating that, even after receiving a proliferative stimulus and undergoing cell division, $\mathrm{N} f 2^{-/-}$hepatocytes can appropriately re-enter a quiescent state. This suggests that either additional mutations cooperate with $N f 2$ loss to drive the development of HCC in this model, or HCC develops from $\mathrm{Nf2^{-/- }}$ progenitors that adopt an improperly differentiated state. Indeed, recent studies document the development of HCC from OCs in carcinogen-treated rats, and suggest that a subset of human HCCs exhibit a gene expression signature that is similar to that of both rodent OCs and HBs (Lee et al. 2006; Andersen et al. 2010).

These models of liver-specific Nf2 deficiency provide a unique opportunity to identify the molecular signals that regulate homeostasis of both embryonic and adult liver progenitors. We found that deletion of $N f 2$ in the liver, as in other cell types, yields deregulated EGFR signaling, and that pharmacologic EGFR inhibitors reverse the overproliferation of $N f 2^{-l-}$ progenitors in vitro 

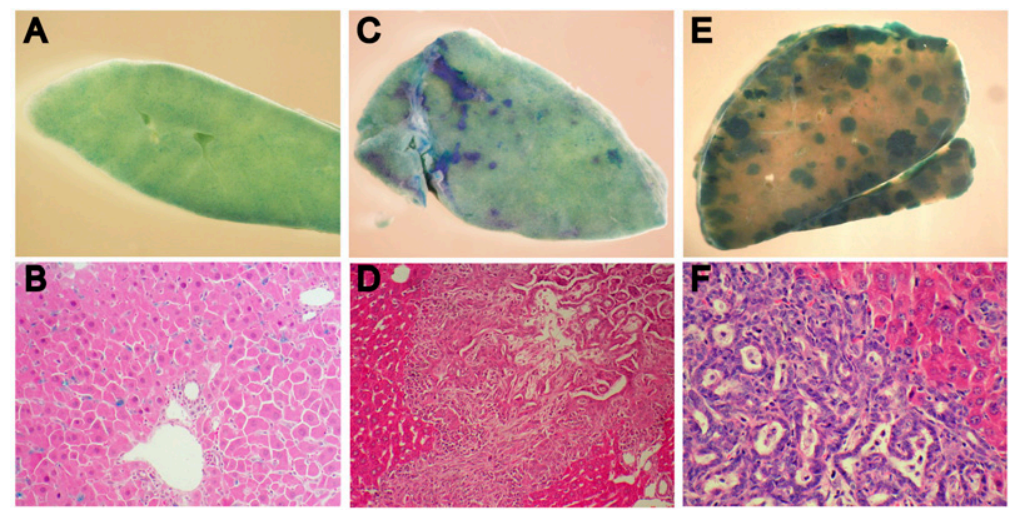

Figure 7. Transplantation of clonal $N f 2^{-/-} \mathrm{HBs}$ into the liver of immunocompromised mice yields OC hyperplasia and cholangiocellular tumors. $(A, B)$ Five weeks after transplantation into the liver of nude mice, control HBs are distributed uniformly throughout the liver parenchyma, as indicated by $L a c Z$ expression detected by whole-mount (a section of the tissue shown in $A$ is presented in $B)$. $(C-F)$ Five weeks after transplantation, $\mathrm{Ad}$-Cre-infected, $\mathrm{Nf2}$ deficient $\mathrm{HBs}$ form multiple foci of undifferentiated LacZ-positive cells $(C)$ that progress to neoplasias $(E)$ exhibiting both hepatocytic and cholangiocytic features $(D, F)$. Hematoxylin and eosin-stained sections are shown in $D$ and $F .(B, D) 200 \times .(F) 400 \times$. and in vivo (Fig. 4; Curto et al. 2007). This, together with the superinduction of EGFR activity in the induced $M x$ Cre; $N f 2^{l o x / l o x}$ liver, strongly supports a primary role for aberrant EGFR activity in OC expansion and tumorigenesis in the absence of $\mathrm{Nf2}$, although other receptors may also be important (McClatchey and Giovannini 2005; Maitra et al. 2006). This is consistent with many studies that have indicated a causal role for EGFR signaling in OC proliferation and liver tumorigenesis in humans and mice (Jhappan et al. 1990; Evarts et al. 1993; Nagy et al. 1996; Yoon et al. 2004; Breuhahn et al. 2006; Blechacz and Gores 2008). Although NF2 mutations have not yet been reported in human liver cancers, our data argue for a systematic mutational analysis across a large, diverse panel of liver tumors; indeed, NF2 mutations could be unique to a subset of tumors that are of progenitor cell origin (Lee et al. 2006; Roskams 2006; Sell and Leffert 2008; Andersen et al. 2010). In fact, the broad consequences of Nf2 loss in development and tumorigenesis in the mouse predict an underappreciated role for NF2 mutations in human cancer. As such, our discovery that kidney-specific Nf2 deletion yields renal carcinomas in the mouse has been complemented recently by the discovery of NF2 mutations in a subset of sporadic human renal tumors (Forbes et al. 2008; Morris and McClatchey 2009; Dalgliesh et al. 2010).

Despite the recent assertion that a critical function of Merlin is to negatively regulate the Hpo/Wts/Yki tumor suppressor pathway in Drosophila (Hamaratoglu et al. 2006, 2009; Baumgartner et al. 2010; Genevet et al. 2010; Yu et al. 2010), together with recent studies linking the corresponding mammalian Mst/Lats/Yap pathway to liver tumorigenesis in mice and humans (Zender et al. 2006; Dong et al. 2007; Zhou et al. 2009; Lu et al. 2010; Song et al. 2010), our studies suggest an important function for Merlin in the liver that is independent of this pathway. Indeed, the reported consequences of inactivating the Mst/Lats/Yap pathway in the liver, either by eliminating Mst1/2 or overexpressing YAP, are quite distinct from that of deleting Nf2 (Camargo et al. 2007; Dong et al. 2007; Zhou et al. 2009; Lu et al. 2010; Song et al. 2010). In fact, overexpression of YAP or deletion of its negative regulators, Mst1 and Mst2, in the liver primarily affects hepatocytes, yielding aberrant hepatocyte morphology, proliferation, and, eventually, HCC that is not pre- ceded by OC expansion (Camargo et al. 2007; Zhou et al. 2009; Lu et al. 2010; Song et al. 2010). In contrast, deletion of $N f 2$ in the liver specifically yields an early and dramatic expansion of progenitor cells without detectable alterations in neighboring hepatocytes, including any increase in nuclear Yap1 (data not shown). Instead, high levels of cytoplasmic and nuclear Yap1 were apparent in some HCC foci and metastases and not in others (Supplemental Fig. 8), suggesting that Nf2 deficiency is not sufficient to yield Yap1 activation in hepatocytes. Instead, it is possible that other mutations cooperate with Nf2 loss to achieve full YAP activation. Similarly, we could not detect a major role for Merlin in regulating Yap1 in OCs, and we found that Yap1 was not required for the overproliferation of cultured OCs. Instead, we provide evidence that the overproliferation of $\mathrm{Nf2}^{-l-}$ liver progenitors in vitro and in vivo is EGFR-dependent.

Our previous molecular studies indicate that Merlin can mediate contact-dependent inhibition of proliferation by coordinating the establishment of cell:cell contact with down-regulation of EGFR signaling (Curto et al. 2007; Cole et al. 2008). In vivo, all cells are in contact, and contact-dependent inhibition of proliferation must be overridden and re-established; for example, during the developmental expansion of tissues. Stem/progenitor cells must be constantly poised to override contact-dependent inhibition of proliferation, and may therefore be particularly sensitive to loss of Merlin function. Indeed, increasing evidence supports a critical role for physical communication between progenitor cells and their niche in governing stem cell division (Fuchs et al. 2004; Scadden 2006). Thus, studies of the relationship between germline stem cells and their niche in Drosophila underscore the importance of reciprocal coordination between intercellular contacts and receptor signaling in controlling niche homeostasis (Yamashita et al. 2005). Similarly, it has been suggested that cadherin-mediated communication between hematopoietic stem cells and the bone marrow niche in mammals governs their proliferation (Adams et al. 2006). Notably, a recent study revealed that Merlin is necessary for the function and structure of the hematopoietic stem cell niche, and, consequently, for limiting hematopoietic stem cell numbers (Larsson et al. 2008). Most studies conclude that the adult liver progenitor cell resides near or at the Canal of Hering, where cholangiocytes 
and hepatocytes come into physical contact with one another (Theise et al. 1999; Paku et al. 2001; Kuwahara et al. 2008). Our studies reveal a key role for Merlin in establishing and maintaining the liver progenitor cell niche. Although further studies will be required to more precisely define the role of Merlin in regulating liver progenitor proliferation in vivo, we speculate that it may function to coordinate physical contacts and growth factor signaling among different cell types in this unique setting of intercellular communication.

\section{Materials and methods}

\section{Animals}

Homozygous $N f 2^{l o x} /$ lox mice $(\mathrm{FVB} / \mathrm{N})$ were crossed with transgenic mice expressing the Cre recombinase under a liver-specific albumin promoter (Alb-Cre) (B6.Cg-Tg[Alb-cre]21Mgn/J; Jackson Laboratories) (Giovannini et al. 2000; Postic and Magnuson 2000) or the Interferon- $\alpha$-inducible $M \times 1$ promoter $(M \times 1-C r e)(\mathrm{Tg}[\mathrm{Mx} 1-$ cre]1Cgn/J; Jackson Laboratories) (Kuhn et al. 1995). To monitor Cre-mediated excision, mice were crossed to the reporter strain


oratories) in which removal of a floxed stop cassette allows expression of the $\beta$-galactosidase/LacZ reporter upon Cre-mediated recombination (Mao et al. 1999). Mixed-gender animals were used for all experiments. Immunocompromised 5-wk-old female $\mathrm{nu} / \mathrm{nu}$ mice used for transplantation experiments were obtained from the Massachusetts General Hospital (MGH) Cox7 facility.

\section{Animal procedures}

All animal procedures were performed according to federal and institutional guidelines, and were approved by the MGH Subcommittee on Research Animal Care. BrdU (Sigma) was injected intraperitoneally at $100 \mathrm{mg} / \mathrm{kg}$ body weight, and mice were sacrificed after $2 \mathrm{~h}$. Activation of the $M x 1$ promoter was induced via two intraperitoneal injections of $250 \mu \mathrm{g}$ of polyIC (Sigma) at 48-h intervals. EGF (Peprotech) was injected intraperitoneally at $10 \mu \mathrm{g} / \mathrm{g}$ body weight, and mice were sacrificed after $30 \mathrm{~min}$. Deletion of $N f 2$ in adult $N f 2^{\text {lox/lox }}$ mouse livers was induced via tail vein injection of $150 \times 10^{6}$ plaque-forming units (pfu) of a Cre-expressing adenovirus (Ad5CMV-Cre; University of Iowa Gene Transfer Vector Core). Compensatory liver cell proliferation was induced by two-third PHx performed according to that described previously in the rat (Higgins and Anderson 1931).

Erlotinib (ChemieTek) was solubilized at $10 \mathrm{mg} / \mathrm{mL}$ in a $6 \%$ $\mathrm{w} / \mathrm{v}$ aqueous solution of Captisol (CyDex Pharmaceuticals). Four Alb-Cre; $N f 2^{l o x} /$ lox and three $N f 2^{\text {lox } / \text { lox }}$ control mice were treated by intraperitoneal injection of erlotinib at $100 \mathrm{mg} / \mathrm{kg}$ body weight once every $12 \mathrm{~h}$ for $10 \mathrm{~d}$. Three $\mathrm{Alb}-\mathrm{Cre} ; \mathrm{Nf2} 2^{\text {lox/lox }}$ and three $N f 2^{\text {lox/lox }}$ control mice were treated on the same schedule with vehicle alone, with no detectable effect.

Transplantation of $3 \times 10^{6} \mathrm{HBs}$ into the livers of 8- to 9-wk-old female nude mice was performed via intrasplenic injection (Ponder et al. 1991). To increase engraftment of transplanted HBs into the liver (Laconi et al. 1998), a proliferative stimulus was provided by a two-third PHx performed at the time of the splenic injection.

\section{Cell culture}

Clonal HB lines were established according to the method described by Strick-Marchand and Weiss (2002) with some modifications. The liver of E14.5 embryos were excised, minced, and dissociated in Liver Dissociation Medium (Gibco-Invitrogen) $\left(30+30\right.$ min rocking at $\left.37^{\circ} \mathrm{C}\right)$, and the cell suspension was plated on two collagen I-coated, 100-mm dishes in F12-DMEM medium (1:1) containing $10 \%$ FBS, $100 \mathrm{ng} / \mathrm{mL}$ EGF, $60 \mathrm{ng} / \mathrm{mL}$ IGF-II, and $10 \mu \mathrm{g} / \mathrm{mL}$ insulin. Cultures were fed with fresh medium twice a week until epithelial clones appeared. Several clones were isolated using cloning cylinders and were further expanded. Nf2 deletion in cultured HBs was achieved via adenoviral expression of the Cre-recombinase as described for mouse embryonic fibroblasts (Lallemand et al. 2003). $\mathrm{Nf}^{-/-}$OC lines (OCs, also dubbed "liver-derived cells" or LDCs) (Curto et al. 2007) were obtained from the liver of a 12 -wk-old AlbCre;Nf2 ${ }^{\text {lox/lox }}$ mouse with marked oval/biliary cell hyperplasia without detectable hepatocellular dysplasia or neoplasia. The liver was excised, minced, and dissociated as described above, and cells were cultured in $10 \%$ FBS-DMEM. Clonal cell lines with uniform epithelial morphologies were established by limiting dilution. The generation and use of adenoviral vectors expressing $N f 2^{\text {wt }}$ have been described (Lallemand et al. 2003). Infections with retroviral vectors encoding Lats2 (Zhang et al. 2008)—shRNAs targeting Yap (sh1877; sh1883; a kind gift of Dr. Lars Zender, Helmholtz Center for Infection Research, Braunschweig, Germany) and Nf2-were performed as described (Cole et al. 2008). Growth curves were performed as described (Curto et al. 2007).

\section{Histology and immunohistochemistry}

Freshly dissected tissues were fixed in $3.7 \%$ formaldehyde-PBS (phosphate-buffered saline), processed, and paraffin-embedded. Five-micron sections were stained with hematoxylin and eosin or processed further for immunohistochemistry. Antigen retrieval was done by boiling in $10 \mathrm{mM}$ citrate buffer $(20 \mathrm{~min}$ ) for Yap1 detection, and $0.1 \%$ trypsin $\left(20 \mathrm{~min}\right.$ at $\left.37^{\circ} \mathrm{C}\right)$ for panCK detection. Sections were incubated for $10 \mathrm{~min}$ in $0.3 \% \mathrm{H}_{2} \mathrm{O}_{2}$-methanol; blocked $1 \mathrm{~h}$ in PBS, $1 \%$ BSA, and $10 \%$ normal goat serum; and incubated overnight at $4{ }^{\circ} \mathrm{C}$ with the following primary antibodies: anti-Yap1 (1:40; Cell Signaling \#4912), anti-panCK (1:1000; Dako \#Z0622). BrdU-labeled cells were detected using a kit (Zymed) following the manufacturer's instructions. The Vectastain Elite kit (Vector Laboratories) was used for HRP-based chromogenic detection of secondary antibodies. Whole-mount LacZ staining of 2 - to 3-mm-thick sections was used to detect $\beta$-galactosidase activity in liver and lung tissues. Freshly dissected tissues were fixed $\left(0.2 \%\right.$ glutaraldehyde, $5 \mathrm{mM}$ EGTA, $2 \mathrm{mM} \mathrm{MgCl}_{2}, 0.1 \mathrm{M}$ $\mathrm{NaPO}_{4}$ buffer at $\mathrm{pH} 7.3$ ), washed three times in wash buffer $(2 \mathrm{mM}$ $\mathrm{MgCl}_{2}, 0.02 \%$ NP-40, $0.01 \%$ deoxycholate, $0.1 \mathrm{M} \mathrm{NaPO}_{4}$ buffer at $\mathrm{pH} 7.3)$, stained overnight in wash buffer $(1 \mathrm{mg} / \mathrm{mL} \mathrm{X-gal,} 5 \mathrm{mM}$ $\mathrm{K}$-ferricyanide, $5 \mathrm{mM} \mathrm{K}$-ferrocyanide) at $37^{\circ} \mathrm{C}$ with gentle agitation, and post-fixed in $3.7 \%$ formaldehyde-PBS. Some specimens were processed further and paraffin-embedded, and $10-\mu \mathrm{m}$ sections were counterstained with eosin or nuclear fast red for histological examination.

Immunofluorescent detection of CD34, panCK, and A6 were carried out on cryosections of frozen, OCT-embedded tissue. Sections were fixed in methanol/acetone $(1: 1, \mathrm{v} / \mathrm{v})$, blocked in $10 \%$ goat serum in PBS for $1 \mathrm{~h}$, and incubated overnight at $4^{\circ} \mathrm{C}$ with primary rat anti-mouse CD34 (1:100; BD-Pharmingen 550537), rabbit anti-cytokeratin (wide spectrum screening; antipanCK) (1:200; Dako Z0622), and rat anti-A6 (1:40; kindly provided by Valentina Factor) in 1\% BSA-PBS, followed by secondary anti-rat Alexa488 (1:200; Molecular Probes) and secondary Cy3conjugated anti-rabbit (1:200; Jackson Immunoresearch Laboratories), respectively, and mounted (Vectashield, Vector Laboratories). Nuclei were stained with DAPI. Two-dimensional epifluorescence images were acquired on a Nikon Eclypse 90i microscope with 
a Q-Imaging 2000R camera and NIS AR2.3 software. Final images were prepared using Adobe Photoshop CS3.

\section{Immunofluorescence}

OCs or HBs were plated on glass coverslips and infected with Ad$\mathrm{Nf2}{ }^{\mathrm{wt}}$ (5 multiplicity of infection [m.o.i.]) or Ad-Cre (20 m.o.i.), respectively, when subconfluent. Four days to $5 \mathrm{~d}$ after reaching confluence, cells were fixed for $15 \mathrm{~min}$ at room temperature in $4 \%$ PFA-cytoskeletal buffer (10 mM 2-[N-Morpholino]ethanesulfonic acid sodium salt [MES] at $\mathrm{pH} 6.3,138 \mathrm{mM} \mathrm{KCl}, 3 \mathrm{mM}$ $\mathrm{MgCl}_{2}, 2 \mathrm{mM}$ EGTA), and were subsequently permeabilized for $15 \mathrm{~min}$ in $0.2 \%$ Triton X-100 in PBS. Coverslips were blocked in $10 \%$ goat serum in PBS for $1 \mathrm{~h}$ and were incubated overnight at $4^{\circ} \mathrm{C}$ with anti-Yap1 (100; Cell Signaling \#49121) in 1\% BSA-PBS. Costaining for Merlin was performed by conjugation of the antiNF2 antibody (1:400; Santa Cruz Biotechnology \#sc-331) with the Zenon Rabbit IgG labeling kit (Molecular Probes) following the manufacturer's instructions. Coverslips were rinsed in PBS, incubated for $1 \mathrm{~h}$ at room temperature in FITC- or Cy3-conjugated secondary antibodies (Jackson Immunoresearch Laboratories), and mounted (Vectashield, Vector Laboratories). Nuclei were stained with DAPI. Two-dimensional epifluorescence images were acquired on a Nikon Eclypse 90i microscope with a Q-Imaging 2000R camera and NIS AR2.3 software. Final images were prepared using Adobe Photoshop CS3.

\section{Immunoblotting}

Liver tissue was homogenized at $4{ }^{\circ} \mathrm{C}$ in $10 \mathrm{vol}(\mathrm{w} / \mathrm{v})$ of RIPA buffer ( $1 \%$ Triton X-100, 0.5\% Na-deoxycholate, $0.1 \%$ SDS, 50 $\mathrm{mM}$ Tris- $\mathrm{HCl}$ at $\mathrm{pH} 7.4,140 \mathrm{mM} \mathrm{NaCl}, 1 \mathrm{mM}$ EDTA, $1 \mathrm{mM}$ EGTA, $1 \mathrm{mM}$ PMSF, $1 \mathrm{mM} \mathrm{Na} 3 \mathrm{VO} 4,10 \mu \mathrm{g} / \mathrm{mL}$ each aprotinin, pepstatin, leupeptin) using a Teflon Potter-Elvehjem tissue grinder. Protein extracts from liver (120 $\mu \mathrm{g}$ per lane) or cultured cells $(30 \mu \mathrm{g}$ per lane) were analyzed by Western blotting using the following primary antibodies: EGFR-pY992 (\#2235), EGFR-pY1068 (\#2234), STAT3-pY705 (\#9145), AKT-pS473 (\#4060), YAP-pS127 (\#4911), and YAP (\#4912), all at 1:1000 (Cell Signaling); NF2 (\#sc-331) at 1:5,000 and EGFR (\#sc-03) at 1:1000 (Santa Cruz Biotechnology); Lats2 (\#A300-479A) at 1:1000 (Bethyl); Orc2 (\#920-4-41) at 1:1000 (BD-Pharmingen). HRP-conjugated secondary anti-mouse and anti-rabbit antibodies were from Amersham. For nuclear/cytoplasmic fractionation, we used the NE-PER kit from Pierce following the manufacturer's instructions.

\section{PCR}

Genotyping PCR from tissues and cells was performed as described for Nf2 (Giovannini et al. 2000), Cre recombinase, and GtRosa26 (Jackson Laboratory; http://jaxmice.jax.org/pub-cgi/ protocols/protocols.sh?objtype=prot_list $)$. For semiquantitative and real-time quantitative RT-PCR, total cellular RNA was extracted with TRIzol (Invitrogen), and reverse-transcribed with MMLV-RT (Promega) using oligo-dT primers. Semiquantitative RT-PCR was carried out as described in Tanimizu et al. (2003) using primers described therein. Fast Start Universal SYBR Green mix (Roche Applied Science) was used to amplify $0.5 \mu \mathrm{L}$ of the RT reaction in a final $25-\mu \mathrm{L}$ volume. Triplicate samples were run on a LightCycler 480 System (Roche Applied Science). Cycling conditions were denaturation for $15 \mathrm{sec}$ at $95^{\circ} \mathrm{C}$, annealing for $1 \mathrm{~min}$ at $60^{\circ} \mathrm{C}$, and extension for $1 \mathrm{~min}$ at $60^{\circ} \mathrm{C}, 40$ cycles. Expression of the $\beta$-actin gene was used as an internal control. Primer sequences in $5^{\prime}$ to $3^{\prime}$ orientation were as follows: AFP, f-TTCGTATTCCAACAG GAGGC and r-CAGACTTCCTGGTCCTGGGC; $\beta$ Actin, $\mathrm{f}-\mathrm{CTA}$ AGGCCAACCGTGAAAAG and r-ACCAGAGGCATACAGGG
ACA; Birc2, f-GAAGAAAATGCTGACCCTACAGA and r-GCTC ATCATGACGACATCTTTC; Birc3, f-AGAGAGGAGCAGATGG AGCA and r-TTTGTTCTTCCGGATTAGTGC; Sox4, f-CCTCG CTCTCCTCGTCCT and r-TCGTCTTCGAACTCGTCGT; Myc, f-CCTAGTGCTGCATGAGGAGA and r-TCTTCCTCATCTTCT TGCTCTTC.

\section{Acknowledgments}

We gratefully acknowledge Othon Iliopoulos and all members of the McClatchey laboratory for helpful discussions and comments on the manuscript, Valentina Factor (NIH, Bethesda) for the A6 antibody, Lars Zender for the Yap shRNA expression vectors, Daniel Haber and Jianmin Zhang for the Lats expression vectors, and Anna Levitz and the Pathology Core Facility for histological support. This work was supported by The International Human Frontier Science Program Organization to S.B., and by grants from the Tucker-Gosnell Foundation, Department of Defense (DOD), National Institutes of Health (NIH), and the Children's Tumor Foundation (CTF) to A.I.M.

\section{References}

Adams GB, Chabner KT, Alley IR, Olson DP, Szczepiorkowski ZM, Poznansky MC, Kos CH, Pollak MR, Brown EM, Scadden DT. 2006. Stem cell engraftment at the endosteal niche is specified by the calcium-sensing receptor. Nature 439: 599-603.

Alison MR. 2005. Liver stem cells: Implications for hepatocarcinogenesis. Stem Cell Rev 1: 253-260.

Andersen JB, Loi R, Perra A, Factor VM, Ledda-Columbano GM, Columbano A, Thorgeirsson SS. 2010. Progenitor-derived hepatocellular carcinoma model in the rat. Hepatology 51: 1401-1409.

Baumgartner R, Poernbacher I, Buser N, Hafen E, Stocker H. 2010. The WW domain protein Kibra acts upstream of Hippo in Drosophila. Dev Cell 18: 309-316.

Blechacz B, Gores GJ. 2008. Cholangiocarcinoma: Advances in pathogenesis, diagnosis, and treatment. Hepatology 48: 308321.

Breuhahn K, Longerich T, Schirmacher P. 2006. Dysregulation of growth factor signaling in human hepatocellular carcinoma. Oncogene 25: 3787-3800.

Camargo FD, Gokhale S, Johnnidis JB, Fu D, Bell GW, Jaenisch R, Brummelkamp TR. 2007. YAP1 increases organ size and expands undifferentiated progenitor cells. Curr Biol 17: 2054-2060.

Cole BK, Curto M, Chan AW, McClatchey AI. 2008. Localization to the cortical cytoskeleton is necessary for Nf2/merlindependent epidermal growth factor receptor silencing. Mol Cell Biol 28: 1274-1284.

Colnot S, Decaens T, Niwa-Kawakita M, Godard C, Hamard G, Kahn A, Giovannini M, Perret C. 2004. Liver-targeted disruption of Apc in mice activates $\beta$-catenin signaling and leads to hepatocellular carcinomas. Proc Natl Acad Sci 101: 17216-17221.

Crosby HA, Kelly DA, Strain AJ. 2001. Human hepatic stemlike cells isolated using c-kit or CD34 can differentiate into biliary epithelium. Gastroenterology 120: 534-544.

Curto M, Cole BK, Lallemand D, Liu CH, McClatchey AI. 2007. Contact-dependent inhibition of EGFR signaling by Nf2/ Merlin. J Cell Biol 177: 893-903.

Dalgliesh GL, Furge K, Greenman C, Chen L, Bignell G, Butler A, Davies H, Edkins S, Hardy C, Latimer C, et al. 2010. Systematic sequencing of renal carcinoma reveals inactivation of histone modifying genes. Nature 463: 360-363. 
Dong J, Feldmann G, Huang J, Wu S, Zhang N, Comerford SA, Gayyed MF, Anders RA, Maitra A, Pan D. 2007. Elucidation of a universal size-control mechanism in Drosophila and mammals. Cell 130: 1120-1133.

Edgar BA. 2006. From cell structure to transcription: Hippo forges a new path. Cell 124: 267-273.

Evarts RP, Nagy P, Marsden E, Thorgeirsson SS. 1987. A precursor-product relationship exists between oval cells and hepatocytes in rat liver. Carcinogenesis 8: 1737-1740.

Evarts RP, Hu Z, Fujio K, Marsden ER, Thorgeirsson SS. 1993. Activation of hepatic stem cell compartment in the rat: Role of transforming growth factor $\alpha$, hepatocyte growth factor, and acidic fibroblast growth factor in early proliferation. Cell Growth Differ 4: 555-561.

Farber E. 1956. Similarities in the sequence of early histological changes induced in the liver of the rat by ethionine, 2-acetylamino-fluorene, and 3'-methyl-4-dimethylaminoazobenzene. Cancer Res 16: 142-148.

Fausto N. 2004. Liver regeneration and repair: Hepatocytes, progenitor cells, and stem cells. Hepatology 39: 1477-1487.

Fausto N, Campbell JS. 2003. The role of hepatocytes and oval cells in liver regeneration and repopulation. Mech Dev 120: $117-130$.

Fausto N, Campbell JS, Riehle KJ. 2006. Liver regeneration. Hepatology 43: S45-S53. doi: 10.1002/hep.20969.

Forbes SA, Bhamra G, Bamford S, Dawson E, Kok C, Clements J, Menzies A, Teague JW, Futreal PA, Stratton MR. 2008. The catalogue of somatic mutations in cancer (COSMIC). Curr Protoc Hum Genet 57: 10.11.1-10.11.26. doi: 10.1002/ 0471142905.hg1011s57.

Fuchs E, Tumbar T, Guasch G. 2004. Socializing with the neighbors: Stem cells and their niche. Cell 116: 769-778.

Genevet A, Wehr MC, Brain R, Thompson BJ, Tapon N. 2010. Kibra is a regulator of the Salvador/Warts/Hippo signaling network. Dev Cell 18: 300-308.

Giovannini M, Robanus-Maandag E, van der Valk M, NiwaKawakita M, Abramowski V, Goutebroze L, Woodruff JM, Berns A, Thomas G. 2000. Conditional biallelic Nf2 mutation in the mouse promotes manifestations of human neurofibromatosis type 2. Genes Dev 14: 1617-1630.

Hamaratoglu F, Willecke M, Kango-Singh M, Nolo R, Hyun E, Tao C, Jafar-Nejad H, Halder G. 2006. The tumour-suppressor genes NF2/Merlin and Expanded act through Hippo signalling to regulate cell proliferation and apoptosis. Nat Cell Biol 8: $27-36$.

Hamaratoglu F, Gajewski K, Sansores-Garcia L, Morrison C, Tao C, Halder G. 2009. The Hippo tumor-suppressor pathway regulates apical-domain size in parallel to tissue growth. I Cell Sci 122: 2351-2359.

Higgins GM, Anderson RM. 1931. Experimental pathology of the liver, I: Restoration of the liver of the white rat following partial surgical removal. Arch Pathol (Chic) 12: 186202.

Jakubowski A, Ambrose C, Parr M, Lincecum JM, Wang MZ, Zheng TS, Browning B, Michaelson JS, Baetscher M, Wang B, et al. 2005. TWEAK induces liver progenitor cell proliferation. J Clin Invest 115: 2330-2340.

Jelnes P, Santoni-Rugiu E, Rasmussen M, Friis SL, Nielsen JH, Tygstrup N, Bisgaard HC. 2007. Remarkable heterogeneity displayed by oval cells in rat and mouse models of stem cell-mediated liver regeneration. Hepatology 45: 1462 1470 .

Jhappan C, Stahle C, Harkins RN, Fausto N, Smith GH, Merlino GT. 1990. TGF $\alpha$ overexpression in transgenic mice induces liver neoplasia and abnormal development of the mammary gland and pancreas. Cell 61: 1137-1146.
Kalamarides $M$, Niwa-Kawakita $M$, Leblois $H$, Abramowski V, Perricaudet M, Janin A, Thomas G, Gutmann DH, Giovannini M. 2002. Nf2 gene inactivation in arachnoidal cells is ratelimiting for meningioma development in the mouse. Genes Dev 16: 1060-1065.

Kiguchi K, Carbajal S, Chan K, Beltran L, Ruffino L, Shen J, Matsumoto T, Yoshimi N, DiGiovanni J. 2001. Constitutive expression of ErbB-2 in gallbladder epithelium results in development of adenocarcinoma. Cancer Res 61: 69716976.

Kofman AV, Morgan G, Kirschenbaum A, Osbeck J, Hussain M, Swenson S, Theise ND. 2005. Dose- and time-dependent oval cell reaction in acetaminophen-induced murine liver injury. Hepatology 41: 1252-1261.

Komuta M, Spee B, Vander Borght S, De Vos R, Verslype C, Aerts R, Yano H, Suzuki T, Matsuda M, Fujii H, et al. 2008. Clinicopathological study on cholangiolocellular carcinoma suggesting hepatic progenitor cell origin. Hepatology 47: 1544-1556.

Kuhn R, Schwenk F, Aguet M, Rajewsky K. 1995. Inducible gene targeting in mice. Science 269: 1427-1429.

Kuwahara R, Kofman AV, Landis CS, Swenson ES, Barendswaard E, Theise ND. 2008. The hepatic stem cell niche: Identification by label-retaining cell assay. Hepatology 47: 19942002.

Laconi E, Oren R, Mukhopadhyay DK, Hurston E, Laconi S, Pani P, Dabeva MD, Shafritz DA. 1998. Long-term, near-total liver replacement by transplantation of isolated hepatocytes in rats treated with retrorsine. Am J Pathol 153: 319-329.

Lallemand D, Curto M, Saotome I, Giovannini M, McClatchey AI. 2003. NF2 deficiency promotes tumorigenesis and metastasis by destabilizing adherens junctions. Genes Dev 17: 1090-1100.

Lallemand D, Manent J, Couvelard A, Watilliaux A, Siena M, Chareyre F, Lampin A, Niwa-Kawakita M, Kalamarides M, Giovannini M. 2009. Merlin regulates transmembrane receptor accumulation and signaling at the plasma membrane in primary mouse Schwann cells and in human schwannomas. Oncogene 28: 854-865.

Larsson J, Ohishi M, Garrison B, Aspling M, Janzen V, Adams GB, Curto M, McClatchey AI, Schipani E, Scadden DT. 2008. $\mathrm{Nf} 2 /$ merlin regulates hematopoietic stem cell behavior by altering microenvironmental architecture. Cell Stem Cell 3: 221-227.

Lee JH, Rim HJ, Sell S. 1997. Heterogeneity of the 'oval-cell' response in the hamster liver during cholangiocarcinogenesis following Clonorchis sinensis infection and dimethylnitrosamine treatment. J Hepatol 26: 1313-1323.

Lee JS, Heo J, Libbrecht L, Chu IS, Kaposi-Novak P, Calvisi DF, Mikaelyan A, Roberts LR, Demetris AJ, Sun Z, et al. 2006. A novel prognostic subtype of human hepatocellular carcinoma derived from hepatic progenitor cells. Nat Med 12: 410-416.

Llovet JM, Burroughs A, Bruix J. 2003. Hepatocellular carcinoma. Lancet 362: 1907-1917.

Lu L, Li Y, Kim SM, Bossuyt W, Liu P, Qiu Q, Wang Y, Halder G, Finegold MJ, Lee JS, et al. 2010. Hippo signaling is a potent in vivo growth and tumor suppressor pathway in the mammalian liver. Proc Natl Acad Sci 107: 1437-1442.

Maitra S, Kulikauskas RM, Gavilan H, Fehon RG. 2006. The tumor suppressors Merlin and Expanded function cooperatively to modulate receptor endocytosis and signaling. Curr Biol 16: 702-709.

Mao X, Fujiwara Y, Orkin SH. 1999. Improved reporter strain for monitoring Cre recombinase-mediated DNA excisions in mice. Proc Natl Acad Sci 96: 5037-5042. 
McClatchey AI, Fehon RG. 2009. Merlin and the ERM proteinsregulators of receptor distribution and signaling at the cell cortex. Trends Cell Biol 19: 198-206.

McClatchey AI, Giovannini M. 2005. Membrane organization and tumorigenesis-the NF2 tumor suppressor, Merlin. Genes Dev 19: 2265-2277.

McClatchey AI, Saotome I, Mercer K, Crowley D, Gusella JF, Bronson RT, Jacks T. 1998. Mice heterozygous for a mutation at the Nf2 tumor suppressor locus develop a range of highly metastatic tumors. Genes Dev 12: 1121-1133.

Michalopoulos GK. 2007. Liver regeneration. J Cell Physiol 213: 286-300.

Morris ZS, McClatchey AI. 2009. Aberrant epithelial morphology and persistent epidermal growth factor receptor signaling in a mouse model of renal carcinoma. Proc Natl Acad Sci 106: 9767-9772.

Morrison H, Sherman LS, Legg J, Banine F, Isacke C, Haipek CA, Gutmann DH, Ponta H, Herrlich P. 2001. The NF2 tumor suppressor gene product, merlin, mediates contact inhibition of growth through interactions with CD44. Genes Dev 15: 968-980.

Murakami H, Sanderson ND, Nagy P, Marino PA, Merlino G, Thorgeirsson SS. 1993. Transgenic mouse model for synergistic effects of nuclear oncogenes and growth factors in tumorigenesis: Interaction of c-myc and transforming growth factor $\alpha$ in hepatic oncogenesis. Cancer Res 53: 1719-1723.

Nagy P, Bisgaard HC, Santoni-Rugiu E, Thorgeirsson SS. 1996. In vivo infusion of growth factors enhances the mitogenic response of rat hepatic ductal (oval) cells after administration of 2-acetylaminofluorene. Hepatology 23: 71-79.

Okada T, Lopez-Lago M, Giancotti FG. 2005. Merlin/NF-2 mediates contact inhibition of growth by suppressing recruitment of Rac to the plasma membrane. J Cell Biol 171: 361-371.

Omori N, Omori M, Evarts RP, Teramoto T, Miller MJ, Hoang TN, Thorgeirsson SS. 1997. Partial cloning of rat CD34 cDNA and expression during stem cell-dependent liver regeneration in the adult rat. Hepatology 26: 720-727.

Paku S, Schnur J, Nagy P, Thorgeirsson SS. 2001. Origin and structural evolution of the early proliferating oval cells in rat liver. Am J Pathol 158: 1313-1323.

Petersen BE, Bowen WC, Patrene KD, Mars WM, Sullivan AK, Murase N, Boggs SS, Greenberger JS, Goff JP. 1999. Bone marrow as a potential source of hepatic oval cells. Science 284: $1168-1170$.

Ponder KP, Gupta S, Leland F, Darlington G, Finegold M, DeMayo J, Ledley FD, Chowdhury JR, Woo SL. 1991. Mouse hepatocytes migrate to liver parenchyma and function indefinitely after intrasplenic transplantation. Proc Natl Acad Sci 88: 1217-1221.

Postic C, Magnuson MA. 2000. DNA excision in liver by an albumin-Cre transgene occurs progressively with age. Genesis 26: $149-150$.

Roskams T. 2006. Liver stem cells and their implication in hepatocellular and cholangiocarcinoma. Oncogene 25: 38183822.

Roskams TA, Theise ND, Balabaud C, Bhagat G, Bhathal PS, Bioulac-Sage P, Brunt EM, Crawford JM, Crosby HA, Desmet $\mathrm{V}$, et al. 2004. Nomenclature of the finer branches of the biliary tree: Canals, ductules, and ductular reactions in human livers. Hepatology 39: 1739-1745.

Sandgren EP, Quaife CJ, Pinkert CA, Palmiter RD, Brinster RL. 1989. Oncogene-induced liver neoplasia in transgenic mice. Oncogene 4: 715-724.

Santoni-Rugiu E, Nagy P, Jensen MR, Factor VM, Thorgeirsson SS. 1996. Evolution of neoplastic development in the liver of transgenic mice co-expressing c-myc and transforming growth factor- $\alpha$. Am J Pathol 149: 407-428.

Scadden DT. 2006. The stem-cell niche as an entity of action. Nature 441: 1075-1079.

Sell S. 2001. Heterogeneity and plasticity of hepatocyte lineage cells. Hepatology 33: 738-750.

Sell S, Leffert HL. 2008. Liver cancer stem cells. J Clin Oncol 26: 2800-2805.

Shiojiri N. 1981. Enzymo- and immunocytochemical analyses of the differentiation of liver cells in the prenatal mouse. J Embryol Exp Morphol 62: 139-152.

Shiojiri N, Lemire JM, Fausto N. 1991. Cell lineages and oval cell progenitors in rat liver development. Cancer Res 51: 2611-2620.

Song H, Mak KK, Topol L, Yun K, Hu J, Garrett L, Chen Y, Park O, Chang J, Simpson RM, et al. 2010. Mammalian Mst1 and Mst2 kinases play essential roles in organ size control and tumor suppression. Proc Natl Acad Sci 107: 1431-1436.

Strick-Marchand H, Weiss MC. 2002. Inducible differentiation and morphogenesis of bipotential liver cell lines from wildtype mouse embryos. Hepatology 36: 794-804.

Tanabe KK, Lemoine A, Finkelstein DM, Kawasaki H, Fujii T, Chung RT, Lauwers GY, Kulu Y, Muzikansky A, Kuruppu D, et al. 2008. Epidermal growth factor gene functional polymorphism and the risk of hepatocellular carcinoma in patients with cirrhosis. JAMA 299: 53-60.

Tanimizu N, Nishikawa M, Saito H, Tsujimura T, Miyajima A. 2003. Isolation of hepatoblasts based on the expression of Dlk/Pref-1. J Cell Sci 116: 1775-1786.

Theise ND. 2006. Gastrointestinal stem cells. III. Emergent themes of liver stem cell biology: Niche, quiescence, self-renewal, and plasticity. Am I Physiol Gastrointest Liver Physiol 290: G189G193. doi: 10.1152/ajpgi.00041.2005.

Theise ND, Saxena R, Portmann BC, Thung SN, Yee H, Chiriboga L, Kumar A, Crawford JM. 1999. The canals of Hering and hepatic stem cells in humans. Hepatology 30: $1425-1433$.

Thorgeirsson SS, Grisham JW. 2006. Hematopoietic cells as hepatocyte stem cells: A critical review of the evidence. Hepatology 43: 2-8.

Xu X, Kobayashi S, Qiao W, Li C, Xiao C, Radaeva S, Stiles B, Wang RH, Ohara N, Yoshino T, et al. 2006. Induction of intrahepatic cholangiocellular carcinoma by liver-specific disruption of Smad4 and Pten in mice. I Clin Invest 116: 1843-1852.

Yamashita YM, Fuller MT, Jones DL. 2005. Signaling in stem cell niches: Lessons from the Drosophila germline. I Cell Sci 118: 665-672.

Yoon JH, Gwak GY, Lee HS, Bronk SF, Werneburg NW, Gores GJ. 2004. Enhanced epidermal growth factor receptor activation in human cholangiocarcinoma cells. I Hepatol 41: 808814.

Yu J, Zheng Y, Dong J, Klusza S, Deng WM, Pan D. 2010. Kibra functions as a tumor suppressor protein that regulates Hippo signaling in conjunction with Merlin and Expanded. Dev Cell 18: 288-299.

Zender L, Spector MS, Xue W, Flemming P, Cordon-Cardo C, Silke J, Fan ST, Luk JM, Wigler M, Hannon GJ, et al. 2006. Identification and validation of oncogenes in liver cancer using an integrative oncogenomic approach. Cell 125: 12531267.

Zhang J, Smolen GA, Haber DA. 2008. Negative regulation of YAP by LATS1 underscores evolutionary conservation of the Drosophila Hippo pathway. Cancer Res 68: 27892794. 
Benhamouche et al.

Zhao B, Lei QY, Guan KL. 2008. The Hippo-YAP pathway: New connections between regulation of organ size and cancer. Curr Opin Cell Biol 20: 638-646.

Zhou D, Conrad C, Xia F, Park JS, Payer B, Yin Y, Lauwers GY, Thasler W, Lee JT, Avruch J, et al. 2009. Mst1 and Mst2 maintain hepatocyte quiescence and suppress hepatocellular carcinoma development through inactivation of the Yap1 oncogene. Cancer Cell 16: 425-438. 


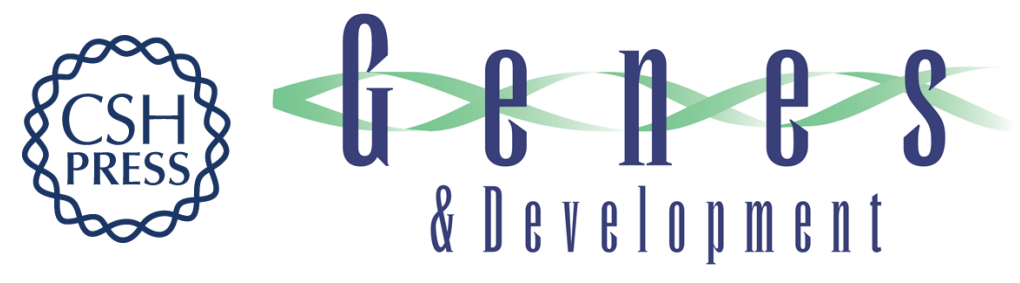

\section{Nf2/Merlin controls progenitor homeostasis and tumorigenesis in the liver}

Samira Benhamouche, Marcello Curto, Ichiko Saotome, et al.

Genes Dev. 2010, 24: originally published online July 30, 2010

Access the most recent version at doi:10.1101/gad.1938710

\section{Supplemental http://genesdev.cshlp.org/content/suppl/2010/07/21/gad.1938710.DC1 \\ Material}

Related Content Merlin in organ size control and tumorigenesis: Hippo versus EGFR?

Chunling Yi and Joseph L. Kissil

Genes Dev. August, 2010 24: 1673-1679

References This article cites 84 articles, 27 of which can be accessed free at:

http://genesdev.cshlp.org/content/24/16/1718.full.html\#ref-list-1

Articles cited in:

http://genesdev.cshlp.org/content/24/16/1718.full.html\#related-urls

\section{License}

Email Alerting

Service

Receive free email alerts when new articles cite this article - sign up in the box at the top right corner of the article or click here.

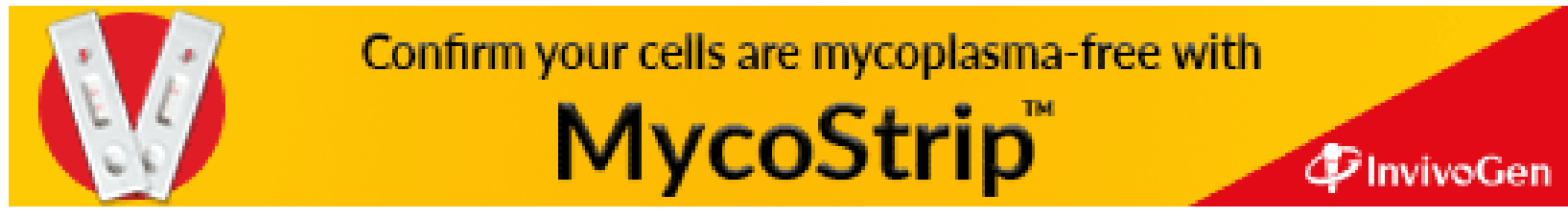

